\title{
RESPONSE OF DIFFERENT PACKAGING AND STORAGE TEMPERATURES ON QUALITY AND BIOACTIVE COMPOUNDS OF ARILS OF POMEGRANATE CV. BHAGWA
}

\author{
K. VENKATARAMUDU ${ }^{1}$, B. SRINIVASULU ${ }^{2} \&$ K. SWARAJYA LAKSHMI ${ }^{3}$ \\ ${ }^{1,3}$ College of Horticulture, Anantharajupeta, Dr. Y. S. R. H. U, Venkataramannagudem, \\ West Godavari, Andhra Pradesh, India \\ ${ }^{2}$ Horticulture Research Station, Ananthapuramu, Dr. Y.S.R.H.U, Venkataramannagudem,
}

West Godavari, Andhra Pradesh, India

\begin{abstract}
Studies were conducted to evaluate the stability of arils of pomegranate cv. Bhagwa in different packaging and

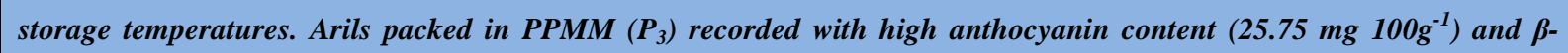
carotene content (33.04 $\left.\mu \mathrm{g} 100 \mathrm{~g}^{-1}\right)$, organoleptic score for colour (6.50), taste (6.25), flavour (6.17) and overall acceptability (6.08) with less microbial count $\left(3.08 \times 10^{8} \mathrm{CFU} / \mathrm{ml}\right)$ was observed. With respect to storage temperatures, arils stored at $S_{1}\left(1^{\circ} \mathrm{C}\right)$ recorded high anthocyanin content $\left(26.80 \mathrm{mg} 100 \mathrm{~g}^{-1}\right)$ and $\beta$-carotene content $\left(36.71 \mu \mathrm{g} 100 \mathrm{~g}^{-1}\right)$ and organoleptic score for colour (7.33), taste (8.22), flavour (7.44) and overall acceptability (6.89) of arils was recorded at $1^{\circ} \mathrm{C}$ with lowest microbial count $\left(1.89 \times 10^{8} \mathrm{CFU} / \mathrm{ml}\right)$. The interaction effect of packing and storage temperatures,

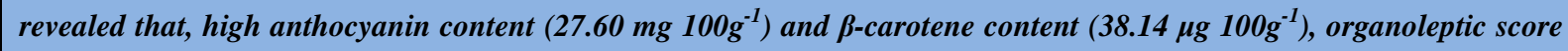
for aril colour (8.00), taste (8.67), flavour (7.67) and overall acceptability (7.67) with lowest microbial count (1.67 $\left.\times 10^{8} \mathrm{CFU} / \mathrm{ml}\right)$ were recorded in $P_{3} S_{1}$.

KEYWORDS: Punica Granatum, Lansky \& Newman
\end{abstract}

Received: Sep 04, 2017; Accepted: Sep 20, 2017; Published: Sep 27, 2017; Paper Id.: IJASROCT201743

\section{INTRODUCTION}

Pomegranate (Punica granatum L.) can be considered as one of the most ideal crops, for the dry Deccan Plateau region of India. Its cultivation has become a highly remunerative agriculture business in India. It is a choicest fruit and is known for its chemo preventive and anti-inflammatory potential, due to its high antioxidant activity (Lansky \& Newman, 2007) and it has exceptional and unique sensory and nutritional properties, such as proteins, carbohydrates, minerals, sugars and crude fibers (Marathe et al. 2010). Now days, due to its enormous health benefits against diabetes, intestinal and cardiovascular disorders dietary preference has been increased, rapidly. Pomegranate fruit and its juice are well known for its antioxidant property and hence becoming popular to prevent cancers of different tissues and organs. In addition to their nutritional composition and sensory attributes, foods are currently recognized as active and protective agents. For the food industry to meet these demands, creative product development, use of new processing and innovative food packaging technologies are needed to maintain product quality and safety as well as assures convenience to the consumer. Among all foods, fresh-cut or minimally processed horticultural produce such as apple, banana, mango, pineapple, watermelon and papaya (Arias et al., 2007 ;) recognize as novel foods with innovative concepts that full fill the demand of modern lifestyle as 
they provide convenience, fresh, safe, nutritious and healthy products. Additionally, pomegranate is one of the fruit which is minimally processed into fresh arils (Ayhan \& Esturk, 2009; Martinezo-Romero et al., 2013). In the last few years, there has been a rapid increase in the demand for industrial processing of pomegranate arils fresh consumption, processed products such as food colorants, tannins for leather, jellies, jams and wines (Caleb, Opara, \& Witthuhn, 2012). Despite these beneficial properties, consumption of pomegranate fruit is not widespread, mainly due to the difficulties involved in removing the arils from fruit (Gil et al., 1996). This limitation promotes the need to process the fruit into minimally processed ready-to-eat arils (Artes et al., 1996; Gil et al., 1996). In modern society, the edible part of the pomegranate fruit is consumed as fresh arils or processed into fresh juice, canned as pastes and jam (Ersan et al., 2010; Martinezo-Romero et al., 2013) food colourants, inks, dyes and tannins for leather. With increasing demand for fresh and natural products without the addition of harmful chemicals, packaging film and storage temperature seems to be an ideal tool for preservation of arils. Selection of right packaging material and ideal temperature is very important for extending the shelf life of arils.

\section{MATERIAL AND METHODS}

The experiment was conducted at Post-Harvest Technology Laboratory, College of Horticulture (COH), Anantharajupet, YSR Kadapa district, Andhra Pradesh during the year, 2015. The fruits of pomegranate varieties, namely, Bhagwa used in the experiment were obtained from AICRP centre on Arid Zone fruits, Horticultural Research Station, Rekulakunta, Ananthapuramu district, Andhra Pradesh. The experiment was conducted in a completely randomized design replicated thrice with 3 packaging materials viz., $\operatorname{PESP}\left(\mathrm{P}_{1}\right)$, PETP $\left(\mathrm{P}_{2}\right)$ and PPMM $\left(\mathrm{P}_{3}\right)$ and storage temperatures $\mathrm{S}_{1}\left(1^{\circ} \mathrm{C}\right)$, $\mathrm{S}_{2}\left(4^{\circ} \mathrm{C}\right), \mathrm{S}_{3}\left(8^{\circ} \mathrm{C}\right)$ and $\mathrm{S}_{3}($ room temperature). The following shelf life parameters were analyzed statistically and the results were presented.

\section{Anthocyanin}

The procedure outlined by Harborne (1973) was used for analyzing anthocyanin content $\left(\mathrm{mg} 100 \mathrm{~g}^{-1}\right)$, in pomegranate arils. One gram of pomegranate arils was macerated in one $\mathrm{ml}$ of methanol, containing one per cent hydrochloric acid. The content was kept overnight at a $0^{\circ} \mathrm{C}$ temperature in a deep freezer. The absorbance of the red colored solution was recorded at $530 \mathrm{~nm}$ on a spectrophotometer. Anthocyanin content was expressed as absorption units at $530 \mathrm{~nm}$ per gram fresh arils.

\section{$\beta$-Carotene}

The $\beta$ - carotene content of pomegranate arils was estimated by using the methodology of Srivastava and Kumar (2003). $\beta$-carotene was extracted from the sample, by crushing one gram of sample with $10 \mathrm{ml}$ acetone and adding crystals of anhydrous sodium sulphate. The supernatant was decanted and collected in a beaker. The process was repeated twice. Ten $\mathrm{ml}$ of petroleum ether was added and mixed thoroughly. The content was transferred into a separating funnel and two layers were separated out on standing solution. Lower layer was discarded and upper layer was collected and the volume was made up to $20 \mathrm{ml}$ with petroleum ether. The optical density was recorded at $452 \mathrm{~nm}$ using petroleum ether as blank.

\section{Moulds and Yeast $\left(\times 10^{8} \mathrm{CFU} / \mathrm{ml}\right)$}

For microbial count estimation, 28g of Nutrient Agar (NA) was suspended in a $1000 \mathrm{ml}$ of distilled water in one beaker and 39g of Potato Dextrose Agar (PDA) in $1000 \mathrm{ml}$ of distilled water in another beaker and both of them heated to 
boiling in order to dissolve the medium completely. After that, sterilization was done by autoclaving at $15 \mathrm{lbs}$ pressure $\left(121^{\circ} \mathrm{C}\right)$ for 15 minutes. Mixed media were poured in Petri-plates in the laminar air flow chamber. The test tubes in the test tube stand were added with $9 \mathrm{ml}$ distilled water in each test tube. After that, the test tubes were sterilized at $15 \mathrm{psi}$ and $121^{\circ} \mathrm{C}$ in autoclave. One gram of aril juice was added in one test tube and labeled as 10 . From this test tube, $1 \mathrm{ml}$ of sample was taken to another test tube and labeled as $10^{-1}$. This step is repeated up to $10^{-3} .100$ micro liter samples were taken and added aseptically with the help of micro pipette in three different NA and PDA plates and spread with the help of a spreader. These plates were kept in BOD incubator (PDA plates at $30^{\circ} \mathrm{C}$ and NA plates at $25^{\circ} \mathrm{C}$ ) for incubation. Count for CFU was done after 48 hours.

\section{Sensory Evaluation}

The stored arils of pomegranate were examined for their sensory qualities by assessing the colour, flavour, texture and overall acceptability. Sensory evaluation was carried out by a panel of 5 judges and the rating was done with a score of 9 points Hedonic scale as proposed by Amerine et al. 1965.

\section{Statistical Analysis}

The data collected were analyzed statistically using factorial completely randomized design as per the procedure outlined by Pence and Sukhatme (1985) and valid conclusions were drawn only on significant differences between treatments mean at 0.05 per cent level of significance.

\section{RESULTS AND DISCUSSIONS}

\section{Anthocyanin Content $\left(\mathrm{mg} \mathrm{100g}^{-1}\right)$}

There were significant differences in anthocyanin $\left(\mathrm{mg} 100 \mathrm{~g}^{-1}\right)$ content of arils packed with different packing material and stored at different storage temperatures (Table 1). Among packing materials, arils packed in PPMM $\left(\mathrm{P}_{3}\right)$

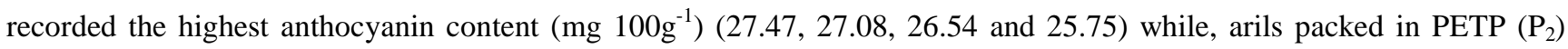

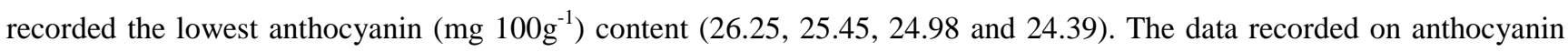

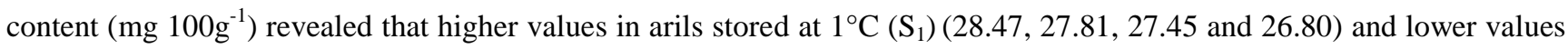
in arils stored at room temperature $\left(\mathrm{S}_{4}\right)(24.85,24.19,23.66$ and 23.01). These results are in agreement with the findings of Artes et al. (2000) and Ayhan and Esturk (2009) in pomegranate cv. Hicaznar.

The interaction between packing material and storage temperatures had significant effect on anthocyanin content $\left(\mathrm{mg} 100 \mathrm{~g}^{-1}\right)$ of arils. Significantly the highest anthocyanin $\left(\mathrm{mg} 100 \mathrm{~g}^{-1}\right)$ content was recorded in PPMM $+1^{\circ} \mathrm{C}\left(\mathrm{P}_{3} \mathrm{~S}_{1}\right)(29.19$, 28.95, 28.62 and 27.60) and lowest anthocyanin content $\left(\mathrm{mg} \mathrm{100g}^{-1}\right)$ in PETP + room temperature $\left(\mathrm{P}_{2} \mathrm{~S}_{4}\right)(24.24,23.83$, 23.15 and 22.54) on $4^{\text {th }}, 8^{\text {th }}, 12 \mathrm{th}^{\text {and }} 16^{\text {th }}$ day of storage. A general trend of decrease in total anthocyanin content of arils was observed as the storage period advanced for all treatments. The decrease in anthocyanin content during storage might be due to oxidative activity of Polyphenol Oxidase (Vamos-Vigyazo, 1981).

\section{$\beta$-Carotene Content $\left(\mu \mathrm{g} 100 \mathrm{~g}^{-1}\right)$}

It is observed from the data presented in Table 2 that, there was significant influence of packing material and storage temperatures on $\beta$-carotene content $\left(\mu \mathrm{g} 100 \mathrm{~g}^{-1}\right)$ of arils. The arils packed in PPMM $\left(\mathrm{P}_{3}\right)$ recorded significantly highest $\beta$-carotene content $\left(\mu \mathrm{g} 100 \mathrm{~g}^{-1}\right)\left(37.27,36.00,34.82\right.$ and 33.04) whereas, PETP $\left(\mathrm{P}_{2}\right)$ recorded the lowest beta-

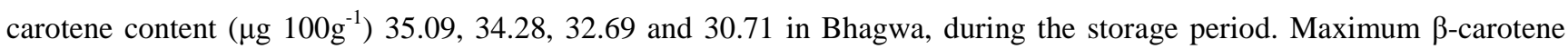




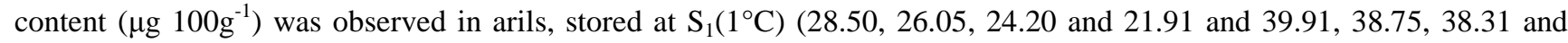
36.71) while, minimum $\beta$-carotene content $\left(\mu \mathrm{g} 100 \mathrm{~g}^{-1}\right)$ was observed in arils stored at $\mathrm{S}_{4}$ (room temperature) $(30.22,28.85$, 25.99 and 22.09) Bhagwa cultivars.

In Bhagwa, the interaction effect was found significant on $4^{\text {th }}, 8^{\text {th }}$ and the 12th day of storage. High $\beta$-carotene content $\left(\mu \mathrm{g} 100 \mathrm{~g}^{-1}\right)$ was recorded in PPMM $+1^{\circ} \mathrm{C}\left(\mathrm{P}_{3} \mathrm{~S}_{1}\right)\left(40.54,39.30\right.$ and 38.97) while, low $\beta$-carotene content $\left(\mu \mathrm{g} 100 \mathrm{~g}^{-}\right.$ $\left.{ }^{1}\right)$ was recorded on PETP + room temperature $\left(\mathrm{P}_{2} \mathrm{~S}_{4}\right)(28.15,27.26$ and 24.18). There were no significant differences observed on $16^{\text {th }}$ day of storage in arils of Bhagwa, with respect to $\beta$-carotene content. There was a reduction in $\beta$-carotene content of arils irrespective of packing, storage temperature and interaction effect, throughout the storage period as also reported by Pilon (2006) in Carrot and Green pepper. This may be due to high solubility of $\beta$-carotene content in water that favor large pigment loss, due to exposure of arils surface to water that is stored during the physiological process like respiration.

\section{Moulds and Yeast $\left(\times 10^{8} \mathrm{CFU} / \mathrm{ml}\right)$}

The data presented in Table 3 showed significant influences of packing material and storage temperatures on the growth of moulds and yeast on arils. The lowest microbial load $\left(\times 10^{8} \mathrm{CFU} / \mathrm{ml}\right)$ was observed in arils packed in PPMM $\left(\mathrm{P}_{3}\right)$ $(0.25,0.92,1.83$ and 3.08$)$ while, highest microbial load $\left(\times 10^{8} \mathrm{CFU} / \mathrm{ml}\right)$ was recorded in PETP $\left(\mathrm{P}_{2}\right)(1.00,2.08,3.33$ and 4.67). With regard to temperatures, no visual detection of mould growth was seen in $\mathrm{S}_{1}\left(1^{\circ} \mathrm{C}\right)$ and $\mathrm{S}_{2}\left(4^{\circ} \mathrm{C}\right)$ whereas, maximum microbial growth was observed at room temperature $\left(\mathrm{S}_{4}\right)(2.00)$ on the 4th day of storage. On the 8th day of storage, there was no visual mould growth seen at $1{ }^{\circ} \mathrm{C}\left(\mathrm{S}_{1}\right)$, while, minimum microbial count $\left(\times 10^{8} \mathrm{CFU} / \mathrm{ml}\right)$ was observed on $8^{\circ} \mathrm{C}\left(\mathrm{S}_{3}\right)(0.33)$ and maximum count $\left(\times 10^{8} \mathrm{CFU} / \mathrm{ml}\right)$ in $\mathrm{S}_{4}$ (room temperature) (3.44 Bhagwa). The lowest microbial load $\left(\times 10^{8} \mathrm{CFU} / \mathrm{ml}\right)$ was observed at $1{ }^{\circ} \mathrm{C}\left(\mathrm{S}_{1}\right)(1.00$ and 1.89$)$ and highest microbial load $\left(\times 10^{8} \mathrm{CFU} / \mathrm{ml}\right)$ was observed at room temperature $\left(\mathrm{S}_{4}\right)(5.00$ and 7.78$)$ during the 12th and 16th day of storage. The importance of storage temperature during storage of pomegranate arils have been emphasised by many researchers, who reported low temperatures $\left(0-5^{\circ} \mathrm{C}\right)$ at modified atmosphere conditions was effective, to reduce respiration rate, enzymatic processes and microbial activity (Gil et al. 1996 b, Kader, 2002 and Nicola et al. 2009).

Significant differences were observed in the interaction effect between packing material and storage temperatures on microbial load $\left(\times 10^{8} \mathrm{CFU} / \mathrm{ml}\right)$ of arils. On $4^{\text {th }}$ day of storage, there was no visual mould growth in $\mathrm{P}_{1} \mathrm{~S}_{1}, \mathrm{P}_{2} \mathrm{~S}_{1}, \mathrm{P}_{3} \mathrm{~S}_{1}, \mathrm{P}_{1} \mathrm{~S}_{2}$, $\mathrm{P}_{2} \mathrm{~S}_{2}, \mathrm{P}_{3} \mathrm{~S}_{2}$ and $\mathrm{P}_{3} \mathrm{~S}_{2}$ whereas, maximum microbial load $\left(\times 10^{8} \mathrm{CFU} / \mathrm{ml}\right)$ was observed in $\mathrm{P}_{2} \mathrm{~S}_{4}$ (4.00). On the 8th day of storage, there was no visual mould growth in $\mathrm{P}_{1} \mathrm{~S}_{1}, \mathrm{P}_{2} \mathrm{~S}_{1}, \mathrm{P}_{3} \mathrm{~S}_{1}, \mathrm{P}_{1} \mathrm{~S}_{2}$ and $\mathrm{P}_{3} \mathrm{~S}_{2}$ while, maximum microbial count $\left(\times 10^{8} \mathrm{CFU} / \mathrm{ml}\right)$ was observed in $\mathrm{P}_{2} \mathrm{~S}_{4}$ (4.67). On $12^{\text {th }}$ day, no significant difference was observed in the interaction effect of arils. On $16^{\text {th }}$ day, significant difference was observed in the interaction effect on microbial count $\left(\times 10^{8} \mathrm{CFU} / \mathrm{ml}\right)$ of arils. Minimum microbial count $\left(\times 10^{8} \mathrm{CFU} / \mathrm{ml}\right)$ was observed in PPMM $+1{ }^{\circ} \mathrm{C}\left(\mathrm{P}_{3} \mathrm{~S}_{1}\right)(1.67)$ and maximum in PETP + room temperature $\left.\left(\mathrm{P}_{2} \mathrm{~S}_{4}\right)\right)$ (9.67). Gil et al. (1996), Kader (2002) and Nicola et al. (2009) reported that no visual detection of mould growth was seen in 'Arakta' and 'Bhagwa' arils stored at $1^{\circ} \mathrm{C}$ after 14 days. Higher storage temperature affected the proximate composition, physico-chemical attributes and bioactive components negatively. This study agrees with other researchers and advises pomegranate producers and retailers that the cold chain should be maintained at low $\left(0-5^{\circ} \mathrm{C}\right)$ storage temperature and $95 \% \mathrm{RH}$ for optimal quality of minimally processed arils of pomegranate. Soliva and Martin Belloso (2003) and Caleb et al. (2013) reported that, the physico-chemical properties of pomegranate arils, such as titratable acidity and cultivar have an important effect on microbial growth and shelf life of fresh cut arils. Gill et al. (1996) 
used the lowest respiration rate as one of the measures to recommend $1{ }^{\circ} \mathrm{C}$, and Modular Mate pack for best quality preservation of pomegranate arils. Storage of arils under optimal MA has been shown to reduce the risk of enterobacteria and lactic acid bacteria as well as moulds and yeast counts (Sepulveda et al. 2000 and Lopez-Rubira et al. 2005 in pomegranate). Furthermore, since the pomegranate arils store at lower temperature, the risk of microbial proliferation was reduced. According to Artes et al. (2000a, b), higher levels of decay were mainly due to Penicillium spp. Similarly, LopezRubira et al. (2005) observed a low count of micro-aerophilic lactic acid bacteria after 10 days of aril storage without any trace of fermentative metabolism.

\section{Organoleptic Evaluation (9 Point Hedonic Scale)}

\section{Colour}

There was a significant effect of packing material and storage temperatures on the sensory qualities of arils during the entire storage period (Table 5). Significantly the highest colour score was recorded in arils packed in PPMM $\left(\mathrm{P}_{3}\right)(7.83$, 7.58, 7.33 and 6.50) and lowest colour score was recorded in arils packed in PETP $\left(\mathrm{P}_{2}\right)(7.00,6.83,5.75$ and 5.25) during the storage period of 16 days. In case of storage temperatures, maximum colour score was recorded in arils stored at $1{ }^{\circ} \mathrm{C}$ $\left(\mathrm{S}_{1}\right)(8.44,8.33,7.78$ and 7.33$)$ and minimum colour score was recorded in arils stored at room temperature $\left(\mathrm{S}_{4}\right)(6.00$, 4.78, 3.89 and 3.00). There were no significant differences observed on the interaction effects of sensory attributes of arils packed with different packing material and storage temperatures throughout the storage period of sixteen days. Similar observation to this finding was also reported by Nanda et al. (2001) in pomegranate when fruits were packed in shrink film.

\section{Taste}

The taste of arils differed significantly with respect to packing material and storage temperatures (Table 6). The best rating for aril taste was recorded in PPMM $\left(\mathrm{P}_{3}\right)$. The maximum rating for aril taste was observed in $\mathrm{P}_{3}(6.67,6.50$, 6.33 and 6.25) and minimum in PETP $\left(\mathrm{P}_{2}\right)(6.17,6.08,5.83$ and 5.75) during the storage period of sixteen days. The highest score for aril taste was recorded at $1^{\circ} \mathrm{C}\left(\mathrm{S}_{1}\right)(9.00,9.00,8.56$ and 8.22) whereas, the lowest score for aril taste was recorded at room temperature $\left(S_{3}\right)(8.11,7.56,7.56$ and 7.22). There were no significant differences observed on the interaction effects of sensory attributes of arils packed with different packing material and storage temperatures throughout the storage period of sixteen days. During the storage period, there was a decreasing trend in organoleptic score, for taste of arils of Bhagwa due to fluctuations in acids, $\mathrm{pH}$ and sugar/acid ratio as reported by Malundo et al. (1991) in mango.

\section{Flavour}

Flavour of the arils packed with different packing materials and stored at different storage temperatures was found to be significant (Table 7). The minimum flavour score was observed in PPMM $\left(\mathrm{P}_{3}\right)(7.33,6.83,6.17$ and 6.17) whereas, maximum of flavour score was observed in PETP $\left(\mathrm{P}_{2}\right)(6.50,6.17,5.50$ and 5.50). Concerned to different temperatures, the lowest off flavour score was observed at $1^{\circ} \mathrm{C}\left(\mathrm{S}_{1}\right)(8.00,7.67,7.44$ and 7.44$)$ while, highest off flavour score was observed at room temperature $\left(\mathrm{S}_{4}\right)(5.11,4.22,3.11$ and 3.11). There were no significant differences observed on the interaction effects of sensory attributes of arils packed with different packing material and storage temperatures throughout the storage period of sixteen days. The maximum score for good flavour of arils appeared to be due to reduced rate of respiration and moisture loss from the arils and also less microbial contamination in the packing materials reported by Nanda et al. (2001) in pomegranate. 


\section{Overall Acceptability}

It is evident from the data presented in Table 7 that the overall acceptability of arils varied significantly and the results were found significant. The highest overall acceptability of arils was recorded in PPMM $\left(\mathrm{P}_{3}\right)(7.58,7.42,7.08$ and 6.08) and lowest overall acceptability of arils was recorded in PETP $\left(\mathrm{P}_{2}\right)(6.67,6.17,6.00$ and 4.58) in Bhagwa cultivar during the storage period. With respect to storage temperatures, the maximum overall acceptability score of arils was recorded at $1{ }^{\circ} \mathrm{C}\left(\mathrm{S}_{1}\right)(8.56,8.11,7.44$ and 6.89$)$ and the minimum overall acceptability score was observed at room temperature $\left(\mathrm{S}_{4}\right)(4.22,4.00,4.00$ and 2.00). The better the organoleptic score for pomegranate arils stored in Modular Mate at lower temperatures could be attributed to the maximum retention of chemical constituents in proper proportions. Similar observations were reported by Nanda et al. (2001) in pomegranate and Rathod et al. (2011) in carambola fruits. The interaction effects of packing material and a storage temperature on the sensory attributes of arils of Bhagwa cultivar was non-significant throughout the storage period. Maintaining the nutritional and organoleptic quality of pomegranate arils is a major challenge, because extracted arils deteriorate in colour, taste, flavour and overall acceptability and a reduction in shelf-life (Gil et al. 1996b). This is due to active metabolic processes by endogenous enzymatic activity and enhanced respiration rate as opined by Rolle and Chism (1987) in fruits and vegetables and Ergun and Ergun (2009) in Pomegranate.

\section{CONCLUSIONS}

Based on the results obtained from the study, it is concluded that, arils of pomegranate cv. Bhagwa packed in polypropylene modular mate (PPMM) and stored at temperature of $1{ }^{\circ} \mathrm{C}$ retained appreciable nutritional, bio-active compound levels and other quality attributes such as aril colour, taste, flavour and overall acceptability at the end of storage period of sixteen days.

\section{REFERENCES}

1. Amerine, M.A, Pangborn, R.M. and Rossler, B.B. 1965. Principles of sensory evaluation of food. Academic press, London.

2. Arias, E., Gonzalez, J., Oria, R. \& Lopez-Buesa, P. 2007. Ascorbic acid and 4-hexylresorcinol effects on pear PPO and PPO catalysed browning reaction. Journal of Food Science, 72(8): 422-429.

3. Artes, F, Tudela, J.A. and Villaescusa, R. 2000a.Thermal postharvest treatment for improvingpomegranate quality and shelf life.Postharvest Biology and Technology. 18: 245-251.

4. Artes, F, Villaescusa, R. and Tudela, J.A. 2000. Modified atmosphere packaging of Pomegranate. Journal of Food Science. 65(7): 1112-1116.

5. Artes, F., Gines Marin, J. \& Martinez, J.A. 1996. Controlled atmosphere packaging of pomegranate. Zeitschrift fuer Lebensmittel-Untersuchung und -Forschung, 203: 33-37.

6. Ayhan, Z. \& Esturk, O. 2009. Overall quality and shelf life of minimally processed and modified atmosphere packaged 'ready-to-eat" pomegranate arils. Journal of Food Science, 74 (5): 399-405.

7. Caleb, O. J., Opara, U. L., \& Witthuhn, C. R. 2012. Modified atmosphere packaging of pomegranate fruit and arils: A review. Food and Bioprocess Technology, 5: 15-30.

8. Caleb, O. J., Opara, U. L., Mahajan, P. V., Manley, M., Mokwena, L., \& Tredoux, A. G. J. (2013). Effect of modified atmosphere packaging and storage temperature on volatile composition and postharvest life of minimally-processed pomegranate arils (cvs. Acco and Herskawitz). Postharvest Biology and Technology, 79, 54-61. 
9. Ergun, M., \& Ergun, N. (2009). Maintaining quality of minimally processed pomegranate arils by honey treatments. British Food Journal, 111(4), 396-406.

10. Ersan, S., Gunes, G. \& Zor, A. O. 2010. Respiration rate of pomegranate arils as affected by $O 2$ and CO2, and design of modified atmosphere packaging. Acta Horticulturae, 876: 189-196.

11. Gil, M. I., Martinez, J. A., \& Artes, F. (1996b). Minimally processed pomegranate seeds. Lebensm Wiss U Technol, 29, 708713. Gontard, N. (2000). Panorama des emballages alimentaires actifs. In N. Gontard (Ed.), Les emballages actifs (pp. 1-29). Paris: Tec \& Doc.

12. Gil, M. I., Martinez, J. A., \& Artes, F. 1996. Minimally processed pomegranate seeds. Lebensmittel-Wissenschaft undTechnologie, 29: 708-713.

13. Gil, M.I., Artes, F., \& Tomas-Barberan, F.A. (1996). Minimal processing and modified atmosphere packaging effects on pigmentation of pomegranate seeds. Journal of Food Science, 61, 1, 161-164.

14. Harborne, J.B. 1973. Phytochemical methods. Chapman and Haul International Education Toppan Company Limited. Tokyo, Japan.

15. Kader, A. A. (2002). Postharvest biology and technology: an overview. In A. A. Kader (Ed.), Postharvest technology of horticultural crops (pp. 39-48). Davis, California, USA: University of California.

16. Lansky, E. P., \& Newman, R. A. 2000. Punica granatum (pomegranate) and its potential for prevention and treatment of inflammation and cancer. Journal of Ethnopharmacology, 109: 177-206.

17. Lopez-Rubira, V, Conesa, A, Allende, A. andArtes, F. 2005. Shelf life and overall quality of minimally processed pomegranate arils modified atmosphere packaged and treated with UV-C. Postharvest Biology and Technology. 37:174-85.

18. Malundo, T.M.M, Baldwin, E.A, Moshonas, M.G, Baker, R.A. and Shewfelt, R.L. 1997. Method for the rapid head space analysis of mango (Mangiferaindica L.) homogenate volatile constituents and factors affecting quantitative results. Journal of Agricultural Food Chemistry. 45(6): 2187-2194.

19. Marathe R A, Chandra R and Jadhav V T. 2010. Influence of different potting media on soil properties, plant nutrient content and nutrient uptake by pomegranate (Punica granatum) seedlings. Indian Journal of Agricultural Sciences 80 (6): 544-7.

20. Martinez-Romero, D., Castillo, S., Guillen, F., Diaz-Mula, H. M., Zapata, P. J., Valero, D. \& Serrano, M. 2013. Aloevera gel coating maintains quality and safety of ready-to-eat pomegranate arils. Postharvest Biology and Technology, 86: 107-112.

21. Nanda, S. Rao, D.V.S. and Shantha-Krishnamurthy. 2001. Effects of shrink film wrapping and storage temperature on the shelf life and quality of pomegranate fruits cv. Ganesh. Post harvest Biology and Technology. 22(1): 61-69.

22. Nicola, S, Tibaldi, G. and Fontana, E. 2009. Fresh-cut produce quality: Implications for a systems approach. In: Postharvest Handling: A Systems Approach. (edited by Florkowski, W.J, Shewfelt, R. L, Brueckner, B. and Prussia, S.E.). 270-273.

23. Panse, V.G. and Sukhatme, P.V. 1985. Statistical methods of agricultural workers. Indian Council of Agricultural Research, New Delhi.

24. Pilon, L, Marilia Oetterer, M, Claudio, R, Marta, H.F. 2006. Shelf life of minimally processed carrot and green pepper. 26(1): 150-158.

25. Rathod, A, Shoba, H. and Chidanand, D.V. 2011. A study on shelf life extension of carambola fruits. International Journal of Scientific and Engineering Research 2(9): 1-5.

26. Rolle, R.S. and Chism, G.W. 1987. Physiological consequences of minimally processed fruits and vegetables. Journal of Food 
Quality. 10:157-77

27. Sepulveda, E, Galletti, l, Saenz, C. and Tapia, M. 2000. Minimal processing of pomegranate Wonderful variety. Symposium on production, processing and marketing of pomegranate in the Mediterranean region: Advances in Research and Technology. 237-242.

28. Soliva, F.R.C.and Martin Belloso. 2003. New advances in extending shelf-life of fresh-cut fruits: a review. Trends in Food Science and Technology. 14:341-353.

29. Srivastava, R.P. and Kumar, S. 2003. Fruit and Vegetable preservation. Principles and Practices. $3^{\text {rd }}$ edition revised and enlarged edition.

30. Vamos-Vigyazo, L. 1981. Polyphenol oxidase and peroxidase in fruits and vegetables. Critical Reviews in Food Science and Nutrition. 9: 49-127.

\section{APPENDICES}

Table 1: Anthocyanin Content (mg $\left.100 \mathrm{~g}^{-1}\right)$ of Arils of Pomegranate cv. Bhagwa as Influenced by Different Packing Material and Storage Temperatures

\begin{tabular}{|c|c|c|c|c|c|c|c|c|c|c|c|c|c|c|c|c|c|}
\hline \multicolumn{18}{|c|}{ Anthocyanin Content (mg 100 $\left.\mathrm{g}^{-1}\right)$} \\
\hline \multicolumn{18}{|c|}{ Storage Period (Days) } \\
\hline & 0 & \multicolumn{4}{|c|}{4} & \multicolumn{4}{|c|}{8} & \multicolumn{4}{|c|}{12} & \multicolumn{4}{|c|}{16} \\
\hline & & $P_{1}$ & $\mathrm{P}_{2}$ & $\mathrm{P}_{3}$ & Mean & $\mathrm{P}_{1}$ & $\mathrm{P}_{2}$ & $\mathrm{P}_{3}$ & Mean & $P_{1}$ & $\mathrm{P}_{2}$ & $\mathrm{P}_{3}$ & Mean & $\mathrm{P}_{1}$ & $\mathrm{P}_{2}$ & $\mathrm{P}_{3}$ & Mean \\
\hline$S_{1}$ & 31.51 & 28.07 & 28.14 & 29.19 & 28.47 & 27.83 & 26.65 & 28.95 & 27.81 & 27.49 & 26.24 & 28.62 & 27.45 & 27.05 & 25.76 & 27.60 & 26.80 \\
\hline $\mathrm{S}_{2}$ & 31.51 & 27.83 & 26.92 & 28.00 & 27.59 & 27.43 & 26.00 & 27.90 & 27.11 & 26.99 & 25.83 & 27.66 & 26.83 & 26.07 & 25.46 & 27.22 & 26.25 \\
\hline $\mathrm{S}_{3}$ & 31.51 & 25.87 & 25.70 & 27.39 & 26.32 & 25.63 & 25.32 & 26.82 & 25.92 & 25.29 & 24.71 & 25.83 & 25.28 & 24.41 & 23.79 & 24.81 & 24.34 \\
\hline $\mathrm{S}_{4}$ & 31.51 & 25.02 & 24.24 & 25.29 & 24.85 & 24.10 & 23.83 & 24.64 & 24.19 & 23.79 & 23.15 & 24.03 & 23.66 & 23.15 & 22.54 & 23.35 & 23.01 \\
\hline Mean & 31.51 & 26.70 & 26.25 & 27.47 & & 26.25 & 25.45 & 27.08 & & 25.89 & 24.98 & 26.54 & & 25.17 & 24.39 & 25.75 & \\
\hline \multicolumn{2}{|c|}{ Statistics } & \multicolumn{2}{|c|}{ S.Em \pm} & \multicolumn{2}{|c|}{$\mathrm{CD} @ \mathrm{P}=0.05$} & \multicolumn{2}{|c|}{ S.Em \pm} & \multicolumn{2}{|c|}{$\mathrm{CD} @ \mathrm{P}=0.05$} & \multicolumn{2}{|c|}{ S.Em \pm} & \multicolumn{2}{|c|}{$\mathrm{CD} @ \mathrm{P}=0.05$} & \multicolumn{2}{|c|}{ S.Em \pm} & \multicolumn{2}{|c|}{$\mathrm{CD} @ \mathrm{P}=0.05$} \\
\hline \multicolumn{2}{|c|}{$\mathrm{P}$} & \multicolumn{2}{|c|}{0.039} & \multicolumn{2}{|c|}{0.113} & \multicolumn{2}{|c|}{0.033} & \multicolumn{2}{|c|}{0.096} & \multicolumn{2}{|c|}{0.034} & \multicolumn{2}{|c|}{0.098} & \multicolumn{2}{|c|}{0.044} & \multicolumn{2}{|c|}{0.128} \\
\hline \multicolumn{2}{|l|}{$S$} & \multicolumn{2}{|c|}{0.045} & \multicolumn{2}{|c|}{0.130} & \multicolumn{2}{|c|}{0.038} & \multicolumn{2}{|c|}{0.111} & \multicolumn{2}{|c|}{0.039} & \multicolumn{2}{|c|}{0.113} & \multicolumn{2}{|c|}{0.051} & \multicolumn{2}{|c|}{0.148} \\
\hline \multicolumn{2}{|l|}{$\mathrm{P} \times \mathrm{S}$} & 0.0 & & 0.2 & 225 & & & 0.1. & & & & & 196 & 0.0 & & & 256 \\
\hline
\end{tabular}

Table 2: Effect of Different Packing Material and Storage Temperatures on $\beta$-Carotene Content $\left(\mu \mathrm{g} 100 \mathrm{~g}^{-1}\right)$ of Arils of Pomegranate cv. Bhagwa

\begin{tabular}{|c|c|c|c|c|c|c|c|c|c|c|c|c|c|c|c|c|c|}
\hline \multicolumn{18}{|c|}{$\beta$-Carotene Content $\left(\mu \mathrm{g} 100 \mathrm{~g}^{-1}\right)$} \\
\hline \multicolumn{18}{|c|}{ Storage Period (Days) } \\
\hline & 0 & \multicolumn{4}{|c|}{4} & \multicolumn{4}{|c|}{8} & \multicolumn{4}{|c|}{12} & \multicolumn{4}{|c|}{16} \\
\hline & & $\mathrm{P}_{1}$ & $\mathrm{P}_{2}$ & $\mathrm{P}_{3}$ & Mean & $\mathrm{P}_{1}$ & $\mathrm{P}_{2}$ & $P_{3}$ & Mean & $\mathrm{P}_{1}$ & $\mathrm{P}_{2}$ & $\mathrm{P}_{3}$ & Mean & $P_{1}$ & $\mathrm{P}_{2}$ & $\mathrm{P}_{3}$ & Mean \\
\hline$S_{1}$ & 42.20 & 40.29 & 38.89 & 40.54 & 39.91 & 39.05 & 37.89 & 39.30 & 38.75 & 38.72 & 37.23 & 38.97 & 38.31 & 36.40 & 35.58 & 38.14 & 36.71 \\
\hline $\mathrm{S}_{2}$ & 42.20 & 39.47 & 38.14 & 39.88 & 39.16 & 37.98 & 37.40 & 38.89 & 38.09 & 37.48 & 36.49 & 38.23 & 37.40 & 35.66 & 34.75 & 36.24 & 35.55 \\
\hline $\mathrm{S}_{3}$ & 42.20 & 36.07 & 35.16 & 36.49 & 35.91 & 35.25 & 34.58 & 35.83 & 35.22 & 33.51 & 32.85 & 34.42 & 33.59 & 32.85 & 32.43 & 33.43 & 32.90 \\
\hline $\mathrm{S}_{4}$ & 42.20 & 30.33 & 28.15 & 32.17 & 30.22 & 29.28 & 27.26 & 30.00 & 28.85 & 26.13 & 24.18 & 27.67 & 25.99 & 21.84 & 20.08 & 24.33 & 22.09 \\
\hline Mean & 42.20 & 36.54 & 35.09 & 37.27 & & 35.39 & 34.28 & 36.00 & & 33.96 & 32.69 & 34.82 & & 31.69 & 30.71 & 33.04 & \\
\hline \multicolumn{2}{|c|}{ Statistics } & \multicolumn{2}{|c|}{ S. Em \pm} & \multicolumn{2}{|c|}{$\mathrm{CD} @ \mathrm{P}=0.05$} & \multicolumn{2}{|c|}{ S. Em \pm} & \multicolumn{2}{|c|}{$\mathrm{CD} @ \mathrm{P}=0.05$} & \multicolumn{2}{|c|}{ S.Em \pm} & \multicolumn{2}{|c|}{$\mathrm{CD} @ \mathrm{P}=0.05$} & \multicolumn{2}{|c|}{ S.Em \pm} & \multicolumn{2}{|c|}{$\mathrm{CD} @ \mathrm{P}=0.05$} \\
\hline \multicolumn{2}{|c|}{$\mathrm{P}$} & \multicolumn{2}{|c|}{0.09} & \multicolumn{2}{|c|}{0.26} & \multicolumn{2}{|c|}{0.08} & \multicolumn{2}{|c|}{0.23} & \multicolumn{2}{|c|}{0.11} & \multicolumn{2}{|c|}{0.33} & \multicolumn{2}{|c|}{0.18} & \multicolumn{2}{|c|}{0.53} \\
\hline \multirow{2}{*}{\multicolumn{2}{|c|}{$\frac{S}{P \times S}$}} & \multirow{2}{*}{\multicolumn{2}{|c|}{$\frac{0.10}{0.18}$}} & & 30 & & 09 & & & 0. & 13 & & 38 & 0. & 21 & & 61 \\
\hline & & & & \multicolumn{2}{|c|}{052} & \multicolumn{2}{|c|}{0.16} & \multicolumn{2}{|c|}{046} & \multicolumn{2}{|c|}{022} & \multicolumn{2}{|c|}{0.65} & \multicolumn{2}{|c|}{0.36} & \multicolumn{2}{|c|}{ NS } \\
\hline
\end{tabular}


Table 3: Effect of Different Packing Material and Storage Temperatures on Microbial Count $\left(\times 10^{8} \mathrm{CFU} / \mathrm{ml}\right)$ of Arils of Pomegranate cv. Bhagwa

\begin{tabular}{|c|c|c|c|c|c|c|c|c|c|c|c|c|c|c|c|c|c|}
\hline \multicolumn{18}{|c|}{ Microbial Count $\left(\times 10^{8} \mathrm{CFU} / \mathrm{ml}\right)$} \\
\hline \multicolumn{18}{|c|}{ Storage Period (Days) } \\
\hline & $\mathbf{0}$ & \multicolumn{4}{|c|}{4} & \multicolumn{4}{|c|}{$\mathbf{8}$} & \multicolumn{4}{|c|}{12} & \multicolumn{4}{|c|}{16} \\
\hline & & $\mathbf{P}_{1}$ & $\mathbf{P}_{2}$ & $\mathbf{P}_{3}$ & Mean & $\mathbf{P}_{1}$ & $\mathbf{P}_{2}$ & $\mathbf{P}_{3}$ & Mean & $\mathbf{P}_{1}$ & $\mathbf{P}_{2}$ & $\mathbf{P}_{3}$ & Mean & $\mathbf{P}_{1}$ & $\mathbf{P}_{2}$ & $\mathbf{P}_{3}$ & Mean \\
\hline $\mathrm{S}_{1}$ & 0.0 & 0.00 & 0.00 & 0.00 & 0.00 & 0.00 & 0.00 & 0.00 & 0.00 & 1.00 & 1.33 & 0.67 & 1.00 & 2.00 & 2.00 & 1.67 & 1.89 \\
\hline $\mathrm{S}_{2}$ & 0.0 & 0.00 & 0.00 & 0.00 & 0.00 & 0.00 & 1.00 & 0.00 & 0.33 & 1.67 & 2.33 & 1.33 & 1.78 & 2.33 & 3.00 & 2.00 & 2.44 \\
\hline $\mathrm{S}_{3}$ & 0.0 & 0.33 & 0.67 & 0.00 & 0.33 & 1.67 & 2.67 & 1.33 & 1.89 & 2.00 & 3.67 & 1.67 & 2.44 & 2.67 & 4.00 & 2.33 & 3.00 \\
\hline $\mathrm{S}_{4}$ & 0.0 & 1.33 & 4.00 & 0.67 & 2.00 & 3.33 & 4.67 & 2.33 & 3.44 & 5.33 & 6.00 & 3.67 & 5.00 & 7.33 & 9.67 & 6.33 & 7.78 \\
\hline Mean & 0.0 & 0.42 & 1.17 & 0.17 & & 1.25 & 2.08 & 0.92 & & 2.50 & 3.33 & 1.83 & & 3.58 & 4.67 & 3.08 & \\
\hline \multicolumn{2}{|c|}{ Statistics } & \multicolumn{2}{|c|}{$\mathrm{S} . \mathrm{Em} \pm$} & \multicolumn{2}{|c|}{$\mathrm{CD} @ \mathrm{P}=0.05$} & \multicolumn{2}{|c|}{ S. Em \pm} & \multicolumn{2}{|c|}{$\mathrm{CD} @ \mathrm{P}=0.05$} & \multicolumn{2}{|c|}{ S. Em \pm} & \multicolumn{2}{|c|}{$\mathrm{CD} @ \mathrm{P}=0.05$} & \multicolumn{2}{|c|}{ S. Em \pm} & \multicolumn{2}{|c|}{$\mathrm{CD} @ \mathrm{P}=0.05$} \\
\hline \multicolumn{2}{|c|}{$\mathrm{P}$} & \multicolumn{2}{|c|}{0.10} & \multicolumn{2}{|c|}{0.28} & \multicolumn{2}{|c|}{0.14} & \multicolumn{2}{|c|}{0.42} & \multicolumn{2}{|c|}{0.17} & \multicolumn{2}{|c|}{0.49} & \multicolumn{2}{|c|}{0.17} & \multicolumn{2}{|c|}{0.51} \\
\hline \multicolumn{2}{|l|}{$\mathrm{S}$} & \multirow{2}{*}{\multicolumn{2}{|c|}{0.11}} & \multirow{2}{*}{\multicolumn{2}{|c|}{0.32}} & \multicolumn{2}{|c|}{0.17} & \multicolumn{2}{|c|}{0.49} & \multicolumn{2}{|c|}{0.19} & \multicolumn{2}{|c|}{0.56} & \multicolumn{2}{|c|}{0.20} & \multicolumn{2}{|c|}{0.58} \\
\hline \multicolumn{2}{|l|}{$\mathrm{P} \times \mathrm{S}$} & & & & & 0 . & & & 84 & 0 . & & & $\mathrm{JS}$ & & 35 & & 01 \\
\hline
\end{tabular}

Table 4: Aril Colour of Pomegranate cv. Bhagwa as Influenced by Different Packing Material and Storage Temperatures

\begin{tabular}{|c|c|c|c|c|c|c|c|c|c|c|c|c|c|c|c|c|c|}
\hline \multicolumn{18}{|c|}{ Aril Color (Organoleptic Score) } \\
\hline \multicolumn{18}{|c|}{ Storage Period (Days) } \\
\hline & 0 & \multicolumn{4}{|c|}{4} & \multicolumn{4}{|c|}{8} & \multicolumn{4}{|c|}{12} & \multicolumn{4}{|c|}{16} \\
\hline & & $P_{1}$ & $\mathrm{P}_{2}$ & $\mathrm{P}_{3}$ & Mean & $P_{1}$ & $\mathrm{P}_{2}$ & $\mathrm{P}_{3}$ & Mean & $\mathrm{P}_{1}$ & $\mathrm{P}_{2}$ & $\mathrm{P}_{3}$ & Mean & $P_{1}$ & $\mathrm{P}_{2}$ & $\mathrm{P}_{3}$ & Mean \\
\hline $\mathrm{S}_{1}$ & 9.00 & 8.67 & 8.00 & 8.67 & 8.44 & 8.33 & 8.00 & 8.67 & 8.33 & 8.00 & 7.00 & 8.33 & 7.78 & 7.67 & 6.67 & 8.00 & 7.33 \\
\hline $\mathrm{S}_{2}$ & 9.00 & 8.33 & 7.67 & 8.33 & 8.11 & 8.00 & 8.00 & 8.00 & 8.00 & 7.67 & 7.00 & 8.00 & 7.56 & 7.33 & 6.33 & 7.67 & 7.11 \\
\hline $\mathrm{S}_{3}$ & 9.00 & 7.67 & 7.67 & 7.67 & 7.67 & 7.67 & 7.33 & 8.00 & 7.67 & 7.33 & 6.33 & 7.67 & 7.11 & 6.33 & 6.33 & 6.67 & 6.44 \\
\hline $\mathrm{S}_{4}$ & 9.00 & 6.67 & 4.67 & 6.67 & 6.00 & 4.67 & 4.00 & 5.67 & 4.78 & 3.67 & 2.67 & 5.33 & 3.89 & 3.33 & 1.67 & 4.00 & 3.00 \\
\hline Mean & 9.00 & 7.83 & 7.00 & 7.83 & & 7.17 & 6.83 & 7.58 & & 6.67 & 5.75 & 7.33 & & 6.17 & 5.25 & 6.50 & \\
\hline \multicolumn{2}{|c|}{ Statistics } & \multicolumn{2}{|c|}{ S.Em \pm} & \multicolumn{2}{|c|}{$\mathrm{CD} @ \mathrm{P}=0.05$} & \multicolumn{2}{|c|}{ S. Em \pm} & \multicolumn{2}{|c|}{$\mathrm{CD} @ \mathrm{P}=0.05$} & \multicolumn{2}{|c|}{ S. Em \pm} & \multicolumn{2}{|c|}{$\mathrm{CD} @ \mathrm{P}=0.05$} & \multicolumn{2}{|c|}{ S. Em \pm} & \multicolumn{2}{|c|}{$\mathrm{CD} @ \mathrm{P}=0.05$} \\
\hline \multicolumn{2}{|c|}{$\mathrm{P}$} & \multicolumn{2}{|c|}{0.16} & \multicolumn{2}{|c|}{0.47} & \multicolumn{2}{|c|}{0.12} & \multicolumn{2}{|c|}{0.34} & \multicolumn{2}{|c|}{0.14} & \multicolumn{2}{|c|}{0.40} & \multicolumn{2}{|c|}{0.15} & \multicolumn{2}{|c|}{0.44} \\
\hline \multicolumn{2}{|l|}{$\mathrm{S}$} & \multicolumn{2}{|c|}{0.18} & \multicolumn{2}{|c|}{0.54} & \multicolumn{2}{|c|}{0.14} & \multicolumn{2}{|c|}{0.40} & \multicolumn{2}{|c|}{0.16} & \multicolumn{2}{|c|}{0.46} & \multicolumn{2}{|c|}{0.18} & \multicolumn{2}{|c|}{0.51} \\
\hline \multicolumn{2}{|l|}{$\mathrm{P} \times \mathrm{S}$} & 0. & & & NS & 0 . & & & JS & 0. & 27 & & JS & 0 . & & & NS \\
\hline
\end{tabular}

Table 5: Taste of Arils of Pomegranate cv. Bhagwa as Influenced by Different Packing Material and Storage Temperatures

\begin{tabular}{|c|c|c|c|c|c|c|c|c|c|c|c|c|c|c|c|c|c|}
\hline \multicolumn{18}{|c|}{ Taste (Organoleptic Score) } \\
\hline \multicolumn{18}{|c|}{ Storage Period (Days) } \\
\hline & 0 & \multicolumn{4}{|c|}{4} & \multicolumn{4}{|c|}{8} & \multicolumn{4}{|c|}{12} & \multicolumn{4}{|c|}{16} \\
\hline & & $\mathrm{P}_{1}$ & $\mathrm{P}_{2}$ & $\mathrm{P}_{3}$ & Mean & $\mathrm{P}_{1}$ & $\mathrm{P}_{2}$ & $\mathrm{P}_{3}$ & Mean & $\mathrm{P}_{1}$ & $\mathrm{P}_{2}$ & $\mathrm{P}_{3}$ & Mean & $\mathrm{P}_{1}$ & $\mathrm{P}_{2}$ & $\mathrm{P}_{3}$ & Mean \\
\hline$S_{1}$ & 9.00 & 9.00 & 8.67 & 9.33 & 9.00 & 9.00 & 8.67 & 9.33 & 9.00 & 8.67 & 8.00 & 9.00 & 8.56 & 8.00 & 8.00 & 8.67 & 8.22 \\
\hline $\mathrm{S}_{2}$ & 9.00 & 8.67 & 8.00 & 9.00 & 8.56 & 8.33 & 8.00 & 8.67 & 8.33 & 8.00 & 8.00 & 8.33 & 8.11 & 8.00 & 8.00 & 8.33 & 8.11 \\
\hline $\mathrm{S}_{3}$ & 9.00 & 8.00 & 8.00 & 8.33 & 8.11 & 8.00 & 7.67 & 8.00 & 7.89 & 7.33 & 7.33 & 8.00 & 7.56 & 7.33 & 7.00 & 8.00 & 7.44 \\
\hline $\mathrm{S}_{4}$ & 9.00 & $0.00^{*}$ & $0.00 *$ & $0.00^{*}$ & $0.00 *$ & $0.00^{*}$ & $0.00^{*}$ & $0.00^{*}$ & $0.00 *$ & $0.00^{*}$ & $0.00^{*}$ & $0.00^{*}$ & $0.00 *$ & $0.00^{*}$ & $0.00^{*}$ & $0.00^{*}$ & $0.00^{*}$ \\
\hline Mean & 9.00 & 6.42 & 6.17 & 6.67 & & 6.33 & 6.08 & 6.50 & & 6.00 & 5.83 & 6.33 & & 5.83 & 5.75 & 6.25 & \\
\hline \multicolumn{2}{|c|}{ Statistics } & \multicolumn{2}{|c|}{ S.Em \pm} & \multicolumn{2}{|c|}{$\mathrm{CD} @ \mathrm{P}=0.05$} & \multicolumn{2}{|c|}{ S.Em \pm} & \multicolumn{2}{|c|}{$\mathrm{CD} @ \mathrm{P}=0.05$} & \multicolumn{2}{|c|}{ S.Em \pm} & \multicolumn{2}{|c|}{$\mathrm{CD} @ \mathrm{P}=0.05$} & \multicolumn{2}{|c|}{ S.Em \pm} & \multicolumn{2}{|c|}{$\mathrm{CD} @ \mathrm{P}=0.05$} \\
\hline \multicolumn{2}{|c|}{$\mathrm{P}$} & \multicolumn{2}{|c|}{0.10} & \multicolumn{2}{|c|}{0.28} & \multicolumn{2}{|c|}{0.11} & \multicolumn{2}{|c|}{0.31} & \multicolumn{2}{|c|}{0.10} & \multicolumn{2}{|c|}{0.28} & \multicolumn{2}{|c|}{0.08} & \multicolumn{2}{|c|}{0.24} \\
\hline \multicolumn{2}{|l|}{$S$} & \multicolumn{2}{|c|}{0.11} & \multicolumn{2}{|c|}{0.32} & \multicolumn{2}{|c|}{0.12} & \multicolumn{2}{|c|}{0.36} & \multicolumn{2}{|c|}{0.11} & \multicolumn{2}{|c|}{0.32} & \multicolumn{2}{|c|}{0.10} & \multicolumn{2}{|c|}{0.28} \\
\hline \multicolumn{2}{|l|}{$\mathrm{P} \times \mathrm{S}$} & 0. & 19 & & $S$ & 0. & 22 & & $S$ & 0. & 19 & & NS & 0. & 17 & & NS \\
\hline
\end{tabular}


Table 6: Effect of Different Packing Material and Storage

Temperatures on Flavour of Arils of Pomegranate cv. Bhagwa

\begin{tabular}{|c|c|c|c|c|c|c|c|c|c|c|c|c|c|c|c|c|c|}
\hline \multicolumn{18}{|c|}{ Flavour of Arils (Organoleptic Score) } \\
\hline \multicolumn{18}{|c|}{ Storage Period (Days) } \\
\hline & 0 & \multicolumn{4}{|c|}{4} & \multicolumn{4}{|c|}{8} & \multicolumn{4}{|c|}{12} & \multicolumn{4}{|c|}{16} \\
\hline & & $\mathbf{P}_{1}$ & $\mathbf{P}_{2}$ & $\mathbf{P}_{3}$ & Mean & $\mathbf{P}_{1}$ & $\mathbf{P}_{2}$ & $\mathbf{P}_{3}$ & Mean & $\mathrm{P}_{1}$ & $\mathrm{P}_{2}$ & $\mathbf{P}_{3}$ & Mean & $\mathbf{P}_{1}$ & $\mathrm{P}_{2}$ & $\mathbf{P}_{3}$ & Mean \\
\hline$S_{1}$ & 9.00 & 8.00 & 7.67 & 8.33 & 8.00 & 7.67 & 7.33 & 8.00 & 7.67 & 7.67 & 7.00 & 7.67 & 7.44 & 7.67 & 7.00 & 7.67 & 7.44 \\
\hline $\mathrm{S}_{2}$ & 9.00 & 7.67 & 7.00 & 8.00 & 7.56 & 7.67 & 6.67 & 7.67 & 7.33 & 7.00 & 6.33 & 7.00 & 6.78 & 7.00 & 6.33 & 7.00 & 6.78 \\
\hline $\mathrm{S}_{3}$ & 9.00 & 7.67 & 6.67 & 7.67 & 7.33 & 7.00 & 6.67 & 7.00 & 6.89 & 6.67 & 6.00 & 6.67 & 6.44 & 6.67 & 6.00 & 6.67 & 6.44 \\
\hline $\mathrm{S}_{4}$ & 9.00 & 5.33 & 4.67 & 5.33 & 5.11 & 4.00 & 4.00 & 4.67 & 4.22 & 3.33 & 2.67 & 3.33 & 3.11 & 3.33 & 2.67 & 3.33 & 3.11 \\
\hline Mean & 9.00 & 7.17 & 6.50 & 7.33 & & 6.58 & 6.17 & 6.83 & & 6.17 & 5.50 & 6.17 & & 6.17 & 5.50 & 6.17 & \\
\hline \multicolumn{2}{|c|}{ Statistics } & \multicolumn{2}{|c|}{ S. Em \pm} & \multicolumn{2}{|c|}{$\mathrm{CD} @ \mathrm{P}=0.05$} & \multicolumn{2}{|c|}{ S. Em \pm} & \multicolumn{2}{|c|}{$\mathrm{CD} @ \mathrm{P}=0.05$} & \multicolumn{2}{|c|}{ S. Em \pm} & \multicolumn{2}{|c|}{$\mathrm{CD} @ \mathrm{P}=0.05$} & \multicolumn{2}{|c|}{ S. $\operatorname{Em} \pm$} & \multicolumn{2}{|c|}{$\mathrm{CD} @ \mathrm{P}=0.05$} \\
\hline \multicolumn{2}{|c|}{$\mathrm{P}$} & \multicolumn{2}{|c|}{0.14} & \multicolumn{2}{|c|}{0.42} & \multicolumn{2}{|c|}{0.13} & \multicolumn{2}{|c|}{0.37} & \multicolumn{2}{|c|}{0.14} & \multicolumn{2}{|c|}{0.40} & \multicolumn{2}{|c|}{0.14} & \multicolumn{2}{|c|}{0.40} \\
\hline \multicolumn{2}{|l|}{$\mathrm{S}$} & \multicolumn{2}{|c|}{0.17} & \multicolumn{2}{|c|}{0.49} & \multicolumn{2}{|c|}{0.15} & \multicolumn{2}{|c|}{0.43} & \multicolumn{2}{|c|}{0.16} & \multicolumn{2}{|c|}{0.46} & \multicolumn{2}{|c|}{0.16} & \multicolumn{2}{|c|}{0.46} \\
\hline \multicolumn{2}{|l|}{$\mathrm{P} \times \mathrm{S}$} & & & & IS & & & & NS & & & & $\mathrm{JS}$ & & & & $\mathrm{NS}$ \\
\hline
\end{tabular}

Table 7: Effect of Different Packing Material and Storage Temperatures on Overall Acceptability of Arils of Pomegranate cv. Bhagwa

\begin{tabular}{|c|c|c|c|c|c|c|c|c|c|c|c|c|c|c|c|c|c|}
\hline \multicolumn{18}{|c|}{ Overall Acceptability of Arils (Organoleptic Score) } \\
\hline \multicolumn{18}{|c|}{ Storage Period (Days) } \\
\hline & $\mathbf{0}$ & \multicolumn{4}{|c|}{4} & \multicolumn{4}{|c|}{8} & \multicolumn{4}{|c|}{12} & \multicolumn{4}{|c|}{16} \\
\hline & & $\mathbf{P}_{1}$ & $\mathrm{P}_{2}$ & $\mathrm{P}_{3}$ & Mean & $\mathbf{P}_{1}$ & $\mathrm{P}_{2}$ & $\mathrm{P}_{3}$ & Mean & $\mathbf{P}_{1}$ & $\mathrm{P}_{2}$ & $\mathbf{P}_{3}$ & Mean & $\mathbf{P}_{1}$ & $\mathbf{P}_{2}$ & $\mathbf{P}_{3}$ & Mean \\
\hline $\mathrm{S}_{1}$ & 9.00 & 8.67 & 8.33 & 8.67 & 8.56 & 8.00 & 7.67 & 8.67 & 8.11 & 7.33 & 7.00 & 8.00 & 7.44 & 7.00 & 6.00 & 7.67 & 6.89 \\
\hline $\mathrm{S}_{2}$ & 9.00 & 8.67 & 8.00 & 8.67 & 8.44 & 8.00 & 7.67 & 8.33 & 8.00 & 7.00 & 7.00 & 8.00 & 7.33 & 6.67 & 5.67 & 7.00 & 6.44 \\
\hline $\mathrm{S}_{3}$ & 9.00 & 7.67 & 7.33 & 8.00 & 7.67 & 7.33 & 6.67 & 8.00 & 7.33 & 6.33 & 6.33 & 7.00 & 6.56 & 6.00 & 5.67 & 6.67 & 6.11 \\
\hline $\mathrm{S}_{4}$ & 9.00 & 4.67 & 3.00 & 5.00 & 4.22 & 4.67 & 2.67 & 4.67 & 4.00 & 3.67 & 3.67 & 5.33 & 4.00 & 2.00 & 1.00 & 3.00 & 2.00 \\
\hline Mean & 9.00 & 7.42 & 6.67 & 7.58 & & 7.00 & 6.17 & 7.42 & & 6.08 & 6.00 & 7.08 & & 5.42 & 4.58 & 6.08 & \\
\hline \multicolumn{2}{|c|}{ Statistics } & \multicolumn{2}{|c|}{ S. Em \pm} & \multicolumn{2}{|c|}{$\mathrm{CD} @ \mathrm{P}=0.05$} & \multicolumn{2}{|c|}{ S. Em \pm} & \multicolumn{2}{|c|}{$\mathrm{CD} @ \mathrm{P}=0.05$} & \multicolumn{2}{|c|}{ S. Em \pm} & \multicolumn{2}{|c|}{$\mathrm{CD} @ \mathrm{P}=0.05$} & \multicolumn{2}{|c|}{ S. Em \pm} & \multicolumn{2}{|c|}{$\mathrm{CD} @ \mathrm{P}=0.05$} \\
\hline \multicolumn{2}{|c|}{$\mathrm{P}$} & \multicolumn{2}{|c|}{0.14} & \multicolumn{2}{|c|}{0.40} & \multicolumn{2}{|c|}{0.14} & \multicolumn{2}{|c|}{0.42} & \multicolumn{2}{|c|}{0.12} & \multicolumn{2}{|c|}{0.34} & \multicolumn{2}{|c|}{0.11} & \multicolumn{2}{|c|}{0.31} \\
\hline \multicolumn{2}{|l|}{$\mathrm{S}$} & \multicolumn{2}{|c|}{0.16} & \multicolumn{2}{|c|}{0.46} & \multicolumn{2}{|c|}{0.17} & \multicolumn{2}{|c|}{0.49} & \multicolumn{2}{|c|}{0.14} & \multicolumn{2}{|c|}{0.40} & \multicolumn{2}{|c|}{0.12} & \multicolumn{2}{|c|}{0.36} \\
\hline \multicolumn{2}{|l|}{$\mathrm{P} \times \mathrm{S}$} & & & & NS & & & & TS & & & & NS & & & & NS \\
\hline
\end{tabular}

Table 8

\begin{tabular}{|l|l|l|l|l|c|l|l|l|}
\hline $\mathrm{P}_{1}$ & - & PESP & $\mathrm{S}_{1}$ & - & $1^{\circ} \mathrm{C}$ & $\mathrm{P}$ & - & Packing material \\
\hline $\mathrm{P}_{2}$ & - & PETP & $\mathrm{S}_{2}$ & - & $4^{\circ} \mathrm{C}$ & $\mathrm{S}$ & - & Storage temperature \\
\hline $\mathrm{P}_{3}$ & - & PPMM & $\mathrm{S}_{3}$ & - & $8^{\circ} \mathrm{C}$ & $\mathrm{P} \times \mathrm{S}$ & - & $\begin{array}{l}\text { Interaction between packing material and } \\
\text { storage temperature }\end{array}$ \\
\hline & & & $\mathrm{S}_{4}$ & - & Room temperature & $*$ & - & Decayed arils \\
\hline
\end{tabular}

